\title{
The Sexually Dimorphic Expression of Androgen Receptors in the Song Nucleus Hyperstriatalis Ventrale Pars Caudale of the Zebra Finch Develops Independently of Gonadal Steroids
}

\author{
Manfred Gahr and Reinhold Metzdorf \\ Max-Planck-Institute of Behavioral Physiology, 82319 Seewiesen, Germany
}

The development of sex differences in brain structure and brain chemistry ("brain sex") of vertebrates is frequently thought to depend entirely on gonadal steroids such as androgens and estrogens, which act on the brain at the genomic level by binding to intracellular transcription factors, the androgen receptors (ARs) and estrogen receptors (ERs). These hormone actions are thought to shift the brain from a monomorphic to a dimorphic phenotype. One prominent such example is the nucleus hyperstriatalis ventrale pars caudale (HVc) of the zebra finch (Poephila guttata), a set of cells in the caudal forebrain involved in the control of singing. In contrast with previous studies using nonspecific cell staining techniques, the size and neuron number of the HVc measured by the distribution of $\mathrm{AR}$ mRNA is already sexually dimorphic on posthatching day (P)9. No ARs or ERs are expressed in the HVc before day 9. Slice cultures of the caudal forebrain of P5 animals show that the

Most models to explain the development of sex differences in the vertebrate brain, and as a consequence, sex differences in behavior, posit a period of primary sex determination in which environmental factors or sex-determining genes specify the sex of the gonad (for review, see Crews, 1993). Gonadal sex determination leads then to the sex-typical production and release of gonadal steroid hormones (androgens and estrogens) according to either a male or a female pattern. The epigenetic action of gonadal steroids is then thought to entirely specify the male- or femaletypical differentiation of the brain, which is initially monomorphic in both sexes (Phoenix et al., 1959; Whalen, 1974; McEwen, 1981; Jost, 1983). Gonadal steroids affect brain development by binding to intracellular steroid receptors, the androgen receptor (AR) and estrogen receptor (ER). Because AR and ER are ligandactivated transcription factors, androgens and estrogens exert their organizational effects on the developing brain at the level of gene transcription, i.e., by genomic mechanisms (for review, see McEwen, 1992).

In contrast to the above scenario, Reisert and Pilgrim (1991) proposed that some sexual dimorphisms in the nervous system develop under primary genetic control. They observed that mesencephalic and hippocampal neurons of the embryonic rat and mouse develop morphological and functional sex differences in the absence of sex steroids in cell cultures (Reisert and Pilgrim,

Received Aug. 4, 1998; revised Dec. 28, 1998; accepted Jan. 10, 1999.

We thank Dr. E. Balaban for comments on an earlier version of this manuscript. Correspondence should be addressed to Dr. Manfred Gahr, Vrije Universiteit Amsterdam, Department of Developmental Neurobiology, Faculty of Biology, De Boolelaan 1087, 1081 HV Amsterdam, The Netherlands.

Copyright (C) 1999 Society for Neuroscience $\quad 0270-6474 / 99 / 192628-09 \$ 05.00 / 0$ sexually dimorphic expression of AR mRNA in HVc is independent of the direct action of steroids on this nucleus or any of its immediate presynaptic or postsynaptic partners. Therefore, gonadal steroids do not appear to be directly involved in the initial sex difference in the expression pattern of AR mRNA, size, and neuron number of the HVc. Furthermore, we demonstrate that the initial steroid-independent size and its subsequent steroidindependent growth by extension linearly with the extension of the forebrain explains $60-70 \%$ of the masculine development of the HVc. Thus, we suggest that epigenetic factors such as the gonadal steroids modify but cannot overwrite the sex difference in HVc volume determined autonomously in the brain.

Key words: sexual dimorphism; androgens; estrogens; zebra finch; vocal control areas; HVc

1991; Reisert et al., 1996; Sibug et al., 1996). This view is further supported by data from hormone treatment studies. Although androgen and/or estrogen treatments of female vertebrates generally induce male-like changes in their brains, the relevant brain areas usually remain structurally dimorphic (e.g., smaller in size) compared with those of males, and behavioral sex reversal is frequently incomplete (Gurney and Konishi, 1980; Gurney, 1982; Döhler et al., 1984; Simpson and Vicario, 1991; Adkins-Regan et al., 1994; Casto and Ball, 1996). These incomplete masculinizations are thought to be caused by suboptimal hormone treatments. In the case of the zebra finch, however, even extended periods of steroid treatment of females result in only partially masculinized vocal control areas (Gurney and Konishi, 1980; Gurney, 1981; Simpson and Vicario, 1991; this study). Furthermore, genetic female zebra finches that develop large amounts of testicular tissue caused by endocrine manipulation in early embryonic life still develop a female-like neural vocal control circuit (Wade and Arnold, 1996). On the basis of these observations, Arnold and colleagues (Arnold, 1996, 1997; Wade and Arnold, 1996) and others (Balthazart and Ball, 1995; Casto and Ball, 1996; Schlinger, 1998) suggested gonadal steroid-independent mechanisms for the sexual differentiation of the vocal control circuit in the zebra finch. However, in a large body of work it was pointed out that the vocal control areas develop first in a monomorphic manner in early posthatching life and become sexually dimorphic later because of the epigenetic action of gonadal steroids (Gurney and Konishi, 1980; Bottjer et al., 1985; Konishi and Akutagawa, 1985; Kirn and DeVoogd, 1989; Simpson and Vicario, 1991; Burek et al., 1995; Nixdorf-Bergweiler, 1996).

The present series of experiments tries further to challenge the 
hegemony of epigenetic, steroid-dependent development of brain sex but attempts as well to combine a steroid-independent mode of differentiation with steroid-dependent differentiation using the vocal control nucleus hyperstriatalis ventrale pars caudale $(\mathrm{HVc})$, a nucleus of the caudal neostriatum of the zebra finch. The vocal control areas such as the HVc are among the quantitatively largest sexual dimorphism in the vertebrate brain (Nottebohm and Arnold, 1976). The HVc is crucial in song control and 8-10 times larger in adult male zebra finches that do sing compared with adult females that do not sing (Nottebohm and Arnold, 1976). This nucleus can be defined in the caudal neostriatum by its cytoarchitecture, its biochemical features such as the expression of AR, and its anterograde and retrograde connections in the vocal control system (for review, see Gahr and Metzdorf, 1997). We show (1) that the AR expression in HVc is sexually dimorphic at the first appearance of AR, whereas no ERs are expressed in the HVc at this time; (2) that the sexually dimorphic expression of ARs in the HVc is independent of any of its immediate presynaptic or postsynaptic partners; and (3) that the sexually dimorphic AR expression is independent of the direct action of steroids on this nucleus. Furthermore, we indicate (4) that the steroid-independent sex difference in $\mathrm{HVc}$ determined autonomously by the brain can be modified but cannot be overwritten by epigenetic factors such as estrogens, because the initial $\mathrm{HVc}$ and its subsequent steroid-independent extension defines $60-70 \%$ of its adult volume. Thus, genomic brain-autonomous mechanisms and epigenetic mechanisms are involved during the sex-specific development of brain and behavior in vertebrates such as the vocal system and singing of the zebra finch.

\section{MATERIALS AND METHODS}

The HVc connections in juvenile zebra finches at posthatching days 5-7. The putative $\mathrm{HVc}$ area in the caudal neostriatum was pressure-injected with biotinylated dextran amine (BDA) (Molecular Probes, Eugene, OR) under isoflurane anesthesia at posthatching day (P)5, P6, and P7 $(n=3$, each group). Three days after the injection, the animals were killed with an overdose of isoflurane. Animals were perfused with RNase-free 4\% phosphate-buffered paraformaldehyde, post-fixed for $2 \mathrm{hr}$, and immersed afterward in RNase-free $20 \%$ phosphate-buffered sucrose. Brains were then frozen and cut into $20 \mu \mathrm{m}$ sections with a cryostat. Adjacent sections were processed for AR and ER in situ hybridizations (see below) and for visualization of retrograde and anterograde labeling. For BDA visualization, sections were presoaked in goat serum $(2 \%$ in $25 \mathrm{~mm}$ PBS and $0.1 \%$ Triton $\mathrm{X}-100$ and $0.3 \% \mathrm{H}_{2} \mathrm{O}_{2}$ ), washed in PBS, incubated in Extravidin (Sigma, St. Louis, MO) (1:100 in PBS) for $1 \mathrm{hr}$, washed in PBS for $30 \mathrm{~min}$, and then reacted with 3,3 diaminobenzidine tetrahydrochloride (Sigma) $(0.2 \mathrm{mg} / \mathrm{ml} \mathrm{PBS})$ and $\mathrm{H}_{2} \mathrm{O}_{2}(0.03 \%)$.

The posthatching growth of the forebrain and of the HVc is by extension. A brain area could increase in size by adding external layers of cells, much like a tree grows, or by spacing out of a founder neuron population, which we call extension. The latter may or may not involve the incorporation of new cells during spacing out. To study the mode of growth of the caudal forebrain in the caudorostral dimension, we injected $10 \mathrm{nl}$ of fluorescin-coated latex microspheres (LumaFluor) and $10 \mathrm{nl}$ of rhodamine-coated latex microspheres (LumaFluor), at $1 \mathrm{~mm}$ caudorostral distance from each other, into the caudal forebrain with a microcapillar mounted onto a $1 \mu \mathrm{l}$ Hamilton syringe. Similar injections were made for the mediolateral and dorsoventral dimension. For each dimension, three males and three females were injected at P10 and killed at P20, injected at P20 and killed at P30, or injected at P30 and killed at P40. Surgery was performed as described above. Animals were decapitated, and brains were removed and frozen over liquid nitrogen. Brains were cut into $40 \mu \mathrm{m}$ parasagittal sections for the dorsoventral dimension, $40 \mu \mathrm{m}$ coronal sections for the mediolateral dimension, and $40 \mu \mathrm{m}$ horizontal sections for the caudorostral dimension. Serial sections were mounted onto Fisher Superfrost Plus Slides. The sections were viewed with an image analysis system (Imatec, Munich, Germany) connected to a Leica fluorescence microscope. The injections resulted in small, rather circular green or red fluorescent areas with the most intensive fluorescence in their center at the end of the injection tract. Because of the mode of cutting, the two injection sites for the caudorostral, mediolateral, or dorsoventral dimension, respectively, could be seen in the same section. The distance between the center of the two injection sites of each brain was then measured with the image analysis system. Because there were no obvious differences between males and females, we calculated an average extension rate based on all six animals per dimension and age group.

With the following investigation we show that the HVc grows by spacing out of an initial founder cell scaffold and incorporation of new cells after P9 (see Fig. 3). Area X-projecting HVc neurons were retrogradely labeled with rhodamine-coated latex microspheres (LumaFluor) after pressure injection of this dye into the area X of the left hemisphere under isoflurane anesthesia at P13 $(n=10)$. Five of these animals were decapitated at P15 and five at P30. The brains were removed, frozen, and cut into $20 \mu \mathrm{m}$ parasagittal sections. Sections were processed for AR mRNA in situ hybridization.

In situ hybridization. AR- and ER-expressing cells were localized in brain sections at various developmental ages with zebra finch-specific cRNA probes by means of in situ hybridization. For the cloning of the zebra finch ARs and ERs, we refer to previous publications (Gahr and Metzdorf, 1997). In situ hybridizations of males and females of the following ages were performed: embryonic day (E)10 (three males, three females), E14 (hatching) $(3,3)$, P3 $(2,2)$, P4 $(2,2)$, P5 $(2,2)$, P6 $(2,2$,$) ,$ P7 $(4,4)$, P8 $(8,8)$, P9 $(10,10)$, P10 $(5,5)$, P15 $(6,6)$, P20 $(6,6)$, P30 (10, $10)$, P100 (adult) (10, 10). Furthermore, estrogen-treated females were analyzed at P9 (8), P15 (6), P20 (6), P30 (10), and P100 (8). For estrogen treatment, female hatchlings were implanted subcutaneously with a SILASTIC pellet prepared according to Gurney (1981) at P5. A pellet contained $90 \mu \mathrm{g}$ of $17 \beta$-estradiol (Sigma).

For transcription of the antisense or sense probes, the plasmids containing the AR or ER sequence were linearized with NsiI and XhoI and transcribed from the SP6 or T7 promotor, respectively. The synthesis and labeling of the probes with ${ }^{35} \mathrm{~S}-\mathrm{CTP}$ (DuPont NEN, Wilmington, DE) was performed using the Riboprobe System (Promega, Madison, WI) according to the manufacturer's instructions. The sense probes served as controls in the in situ hybridization studies.

An in situ hybridization procedure previously described by Whitfield et al. (1990) was followed with modifications. Brains were cut into $20 \mu \mathrm{m}$ parasagittal sections and mounted onto Fisher Superfrost Plus Slides. Sections were mounted onto different slides so that we obtained three series of adjacent sections that were stained for AR and ER and with the Nissl-dye Thionin. Sections were hybridized under coverslips for $15 \mathrm{hr}$ at $55^{\circ} \mathrm{C}$, using ${ }^{35} \mathrm{~S}$-labeled sense or antisense probes $\left(8 \times 10^{6} \mathrm{cpm} / \mathrm{ml}\right)$ in $50 \%$ formamide, $600 \mathrm{~mm} \mathrm{NaCl}, 10 \mathrm{~mm}$ Tris-HCl, $\mathrm{pH} 7.5,0.02 \%$ Ficoll, $0.02 \%$ BSA, $0.02 \%$ polyvinylpyrrolidone, $1 \mathrm{~mm}$ EDTA, $0.01 \%$ salmon testicular DNA, $0.05 \%$ total yeast RNA, $0.005 \%$ yeast transfer RNA, $10 \%$ dextran sulfate, $0.1 \%$ SDS, $0.1 \%$ sodium thiosulfate, and $100 \mathrm{~mm}$ dithiothreitol. After hybridization, slides were immersed in $2 \times$ SSC for $30 \mathrm{~min}$ at room temperature to float off the coverslips. The slides were first treated with RNase-A $(20 \mu \mathrm{g} / \mathrm{ml})$ in RNase buffer $(0.5 \mathrm{M} \mathrm{NaCl}, 10$ $\mathrm{mm}$ Tris-HCl, pH 8.0, $1.0 \mathrm{~mm}$ EDTA) for $30 \mathrm{~min}$ at $37^{\circ} \mathrm{C}$ and washed in the same buffer for $30 \mathrm{~min}$ at $37^{\circ} \mathrm{C}$. The slides were then washed in $2 \times$ SSC for $1 \mathrm{hr}$ at $50^{\circ} \mathrm{C}, 0.2 \times \mathrm{SSC}$ for $1 \mathrm{hr}$ at $55^{\circ} \mathrm{C}$, and $0.2 \times \mathrm{SSC}$ for $1 \mathrm{hr}$ at $60^{\circ} \mathrm{C}$, and then dehydrated sequentially before air drying. To detect autoradiographic silver grains, the slides were dipped into Kodak NTB-2 nuclear track emulsion diluted $1: 1$ with $0.1 \%$ Aerosol 22 (Sigma) at $42^{\circ} \mathrm{C}$ and then exposed at $4^{\circ} \mathrm{C}$ for $7 \mathrm{~d}$. The slides were developed in Kodak D19 for $2 \mathrm{~min}$ at $16^{\circ} \mathrm{C}$, rinsed in water for $30 \mathrm{sec}$, fixed in Kodak fixer for 5 min, and then washed in water. Sections were counterstained with Thionin and examined using bright- and dark-field illumination.

In vivo autoradiographic localization of androgen-binding cells. For the localization of AR protein-containing cells, the cellular uptake of the androgen $5 \alpha$-dihydrotestosterone ( $5 \alpha$-DHT) was studied in autoradiographic procedures. The androgen $5 \alpha$-DHT is not convertible to estrogens. Four P8, four P9, and six P10 male and females were injected intramuscularly with $5 \alpha-\left[{ }^{3} \mathrm{H}\right] \mathrm{DHT}$ [ $5 \mathrm{ng}(3 \mu \mathrm{Ci})$ per gram of body weight $(\mathrm{NEN}, \mathrm{NET}-453)$; specific activity $=4.07 \mathrm{TBq} / \mathrm{mmol}]$ dissolved in $70 \%$ ethanol. The brains were removed 90 min later and frozen over liquid nitrogen. Brains were cut into $20 \mu \mathrm{m}$ parasagittal sections with a cryostat at $-20^{\circ} \mathrm{C}$, and the sections were mounted onto gelatin-coated slides. To detect autoradiographic silver grains, the slides were dipped into Kodak NTB-3 nuclear track emulsion diluted 1:1 with $0.1 \%$ Aerosol 22 (Sigma) at $42^{\circ} \mathrm{C}$ and then exposed at $-80^{\circ} \mathrm{C}$ for 16 weeks. The slides were developed in Kodak D19 for 2 min at $16^{\circ} \mathrm{C}$, rinsed in deionized water for 
$30 \mathrm{sec}$, fixed in Kodak fixer for $5 \mathrm{~min}$, and then washed in deionized water. Sections were counterstained with Thionin and examined using bright- and dark-field illumination.

$R T-P C R$. For the detection of AR mRNA in tissue samples of the developing zebra finch brain, tissue samples were collected using the Palkovits punch technique. Samples were taken of the caudal neostriatum and the hypothalamus of P8 male zebra finches $(n=4)$. For control we used the homologous tissues of adult male zebra finches $(n=3)$ and adult male ring doves (Streptopelia risoria) $(n=2)$. mRNA was prepared from the total RNA using the Dynabeads mRNA Direct Kit (Dynal, Great Neck, NY). The synthesis of the cDNA and the amplification of the cDNA with semi-nested PCR was performed with standard techniques. For the first round of PCR, the $5^{\prime}$ primer was [GC(AC)GCTGAAGG(GT)AAACA] and the $3^{\prime}$ primer was [TC(GA)AGTTCCTTGA TGTA(AG)TTCAT], for the second round of PCR the $5^{\prime}$ primer was [AATCCAGTA CTCTTGGATGG]. These primers correspond to positions in exon $2 / 3$, exon 7 , and exon 5 of the AR, respectively.

Slice cultures. The caudal neostriatum and the anterior neostriatum were cut with a vibratome into 250- $\mu \mathrm{m}$-thick slices at P5. The slices were cultured in a static explant culture system (Millipore Millicell, Millipore, Bedford, MA; $0.4 \mu \mathrm{m})$ in a defined medium that did not contain steroids [F12/DME (Life Technologies, Gaithersburg, MD), $5 \mu \mathrm{g} / \mathrm{ml}$ insulin, 100 $\mu \mathrm{g} / \mathrm{ml}$ transferin, $100 \mu \mathrm{M}$ putrescin, $30 \mathrm{~nm}$ Na-selenit, $100 \mu / \mathrm{ml}$ penicillin/ streptomycin] in a $5 \% \mathrm{CO}_{2}$ atmosphere at $37^{\circ} \mathrm{C}$. Slices were fixed with RNase-free $4 \%$ paraformaldehyde in PBS after 5-8 d in vitro (DIV), immersed in RNase-free $20 \%$ sucrose in PBS, frozen, cut into $20 \mu \mathrm{m}$ sections on a cryostat, and processed for in situ hybridization for the AR mRNA and ER mRNA as described above.

Morphometric analysis. For each animal of the HVc development study, the volume of the AR-defined HVc and of the Nissl-defined H Vc was measured in every third section with an image analysis system on a video screen (Imatec). The volume of the HVc of an animal was the sum of these measurements $\times 3$ multiplied with the section thickness.

The number of neurons of the AR mRNA-defined HVc at P9 was counted in the sections after Nissl staining. At P9, only the comparison of the AR mRNA-labeled sections with the Nissl-stained sections made it possible to identify the HVc in the Nissl stainings (see Results). The cell countings were preformed under high power $(1000 \times)$ with the help of the image analysis system on a video screen. Three $5000 \mu \mathrm{m}^{2}$-counting frames were analyzed in every third section of each animal using the optical dissector technique (Coggeshall, 1992), and the total number of cells was derived from these cell densities and the volume of AR mRNA-defined HVc.

The number of AR mRNA-containing cells in the caudal neostriatum of P9 animals, of P30 animals, and of the slice cultures was counted in the Nissl-counterstained in situ hybridizations under high power $(1000 \times)$ with the help of the image analysis system. A cell was counted as an AR mRNA-expressing cell if the number of grains over the cell exceeded $7 \times$ the background. Background was defined as the mean number of grains over five cell-sized areas of neuropil across the field of analysis. The number of tritium-labeled neurons obtained with in vivo autoradiography was counted with a similar procedure.

We used Kruskal-Wallis nonparametric ANOVA (Conover, 1980) for all statistical comparisons. The $\mathrm{HVc}$ volumes and neuron numbers are given as means $\pm \mathrm{SD}$.

\section{RESULTS}

The HVc is sexually dimorphic at P9 when gonadal steroid receptors are first expressed in the HVc

AR mRNA-expressing cells were found in the hypothalamicpreoptic areas and the midbrain nucleus intercollicularis from E10 onward. In addition, from hatching onward we localized AR mRNA expression cells in hindbrain regions, such as the nucleus hypoglossus pars tracheosyringealis, and in the hippocampus. In the caudal neostriatum (where HVc develops) of male and female zebra finches, AR mRNA-expressing cells were first found at P9 (Figs. 1, 2). At this and all older stages the area of AR-expressing cells is dramatically larger in males compared with females (Figs. 1, 2), e.g., at P9, the AR-defined HVc of males is 2.2 times larger and becomes four times larger at P30. Concomitantly, males have many more AR mRNA-containing cells in this area compared with females. At P9, the male HVc contains 2.2 times more AR
mRNA-expressing cells (male, $2210 \pm 435$; female, $1045 \pm 272$; $p<0.001 ; t=3.992$ ) and 2.1 times the number of cells (male, 27 $700 \pm 2800$; female, $13100 \pm 1900 ; p<0.001 ; t=3.922)$ than the female HVc. At P30, the male HVc contains 3.3 times more AR mRNA-expressing cells than the female HVc (male, $5930 \pm 620$; female, $1800 \pm 410 ; p<0.001 ; t=3.922)$. These data show that the distribution of the AR mRNA is sexually dimorphic right from the beginning of the AR expression in the caudal neostriatum. Because AR mRNA distribution (M. Gahr, unpublished observations) and the distribution of androgen-binding sites (Johnson and Bottjer, 1995) is congruent with the area in the caudal neostriatum that projects to the vocal control nucleus robustus archistriatalis, the AR distribution in the caudal neostriatum delineates HVc. Thus males have a significantly larger HVc compared with females as early as P9 when the first AR mRNA is expressed. ER mRNA-expressing cells were not found in the $\mathrm{HVc}$ area of $\mathrm{P} 9$ or younger animals.

Alternatively to the interpretation that the entire $\mathrm{HVc}$ is sexually dimorphic at P9, only an AR mRNA-expressing sub-area of the HVc might be sexually dimorphic. However, even at P15, the Nissl-defined HVc of males $\left(0.055 \pm 0.016 \mathrm{~mm}^{3}\right)$ and females $\left(0.032 \pm 0.014 \mathrm{~mm}^{3}\right)$ is smaller than the respective AR-defined HVc (males, $0.085 \pm 0.007 \mathrm{~mm}^{3}$; females, $0.05 \pm 0.005 \mathrm{~mm}^{3}$ ). In correlation, at this age the sex difference in $\mathrm{HVc}$ volume is less obvious in Nissl-stained sections $(p<0.05 ; t=2.228)$ compared with the AR-defined delineation of the nucleus $(p<0.001 ; t=$ 4.587). The HVc was ambiguous in Nissl-stained sections at P9 and P10, which did not allow the quantification of the HVc size at these ages. We conclude from these results that AR are first expressed in the HVc at P9 and that the area of expression is sexually dimorphic. The earlier onset of this sexual difference in the HVc anatomy compared with previous studies (Kirn and DeVoogd, 1989; Nixdorf-Bergweiler, 1996) and with our own Nissl-based measurements is attributable to the functional delineation of the HVc using the AR mRNA expression. As shown previously, cytoarchitectural delineations based on Nissl-stained material suffers from a number of uncertainties (Gahr, 1990). From P30 on, the size of the Nissl-defined HVc (P30 male, $0.245 \pm 0.027 \mathrm{~mm}^{3}$; P30 female, $0.052 \pm 0.012 \mathrm{~mm}^{3}$ ) is similar to the AR mRNA-defined HVc (P30 male, $0.231 \pm 0.02 \mathrm{~mm}^{3}$; P30 female, $\left.0.055 \pm 0.011 \mathrm{~mm}^{3}\right)$. One study reported a clear sex difference even in the Nissl-defined HVc as early as P12 (Bottjer et al., 1985).

With RT-PCR we amplified AR mRNA using semi-nested primers in the tissue samples of the juvenile zebra finches, adult zebra finches, and the ring dove. Because the caudal neostriatum of the ring dove was used as a negative control, we subsequently did an androgen-binding study to verify whether the caudal forebrain of P8-P10 zebra finches indeed contains the AR protein.

In the androgen-binding studies with tritiated $5 \alpha$-DHT for the localization of AR, we studied P8, P9, and P10 zebra finches (Fig. $3 A$ ). At $\mathrm{P} 8$, tritium-labeled cells are found in the hippocampus and hypothalamus but not in the HVc. At P9, the first few tritium-labeled cells are seen scattered in the $\mathrm{HVc}$ area of the males, whereas we found tritium-labeled cells in only one female (Fig. 3B). At P10, the $\mathrm{HVc}$ of males and females contained a substantial but sex-specific number of tritium-labeled cells $(p<$ $0.01 ; t=3.169$ ) (Fig. 3B). Because of the scattered distribution of tritium-labeled cells at P9, we quantified the area of androgen binding in the caudal neostriatum only for P10 animals. Similar to the AR mRNA distribution study at P9 (see above), the androgen-binding $\mathrm{HVc}$ was approximately two times larger $(p<$ 
male
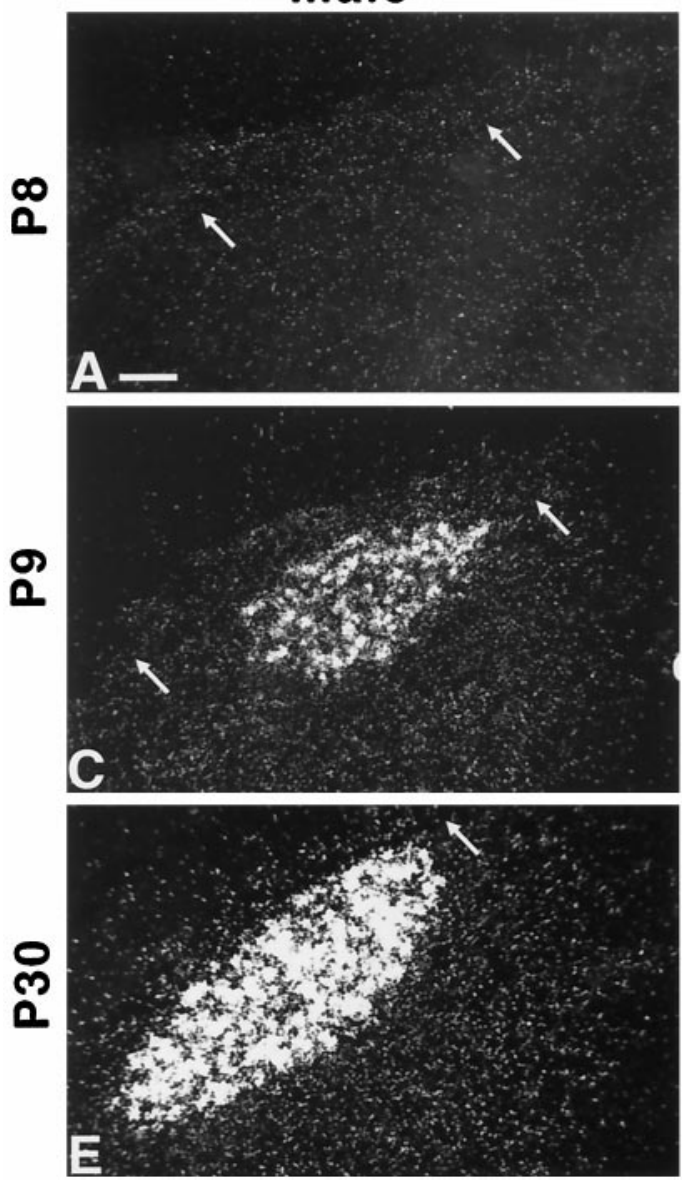
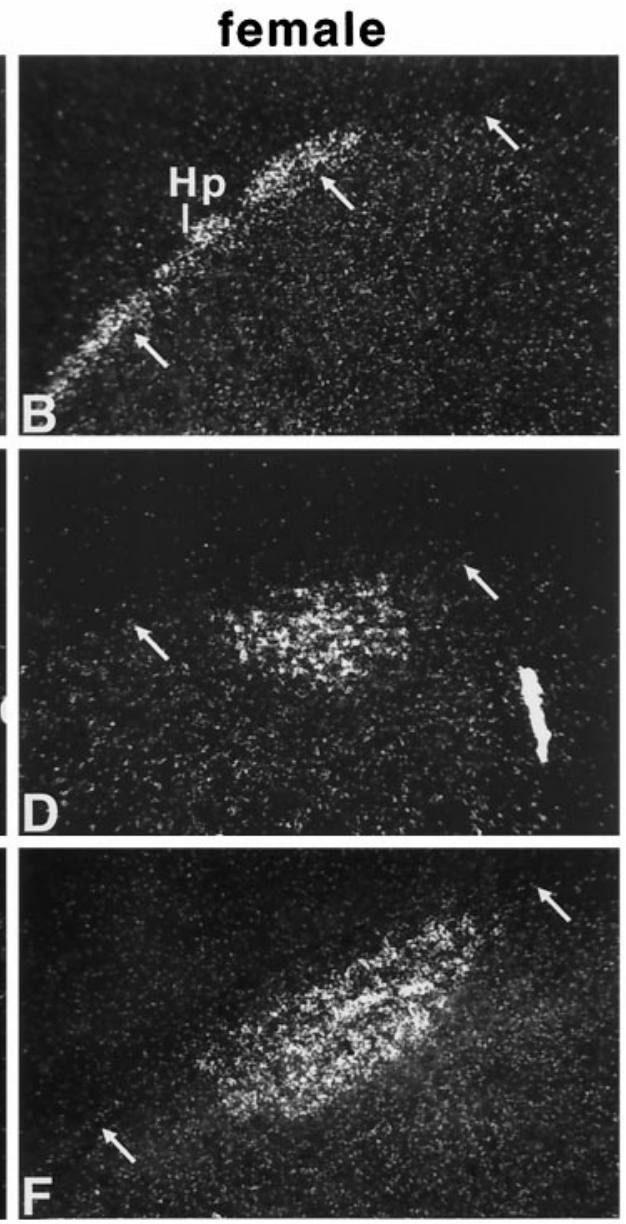

Figure 1. The HVc of the zebra finch is highly sexually dimorphic at posthatching day $9(P 9)$. The AR mRNA distribution was used to map the HVc. $\mathrm{HVc}$ develops ventral to the lateral ventricle (arrows indicate the lateral ventricle) in the caudal neostriatum. AR mRNA-labeled cells in the caudal neostriatum are not present in males $(A)$ or females $(B)$ at P8. At this age we find AR mRNA expressed in the more medial aspect of the hippocampus $(\mathrm{Hp})$ $(B)$, overlaying the caudal neostriatum. $A$ shows a more lateral and $B$ shows a more medial aspect of the caudal neostriatum and hippocampus. There is no sex difference in the AR mRNA expression in the hippocampus. In the caudal neostriatum of male $(C)$ and female (D) zebra finches, AR mRNA is first found at P9. At this time, the male AR mRNA-defined $\mathrm{HVc}$ is 2.2 times larger $(p<0.001 ; t=3.922)$ and contains 2.2 times more $(p<0.001 ; t=3.922)$ AR mRNA-expressing cells than the female $\mathrm{HVc}$. At P30, the male HVc $(E)$ is 3.3 times larger $(p<0.001 ; t=3.922)$ and contains three times more $(p<0.001$; $t=3.922)$ AR mRNA-expressing cells than the female HVc $(F)$. Scale bar, $50 \mu \mathrm{m}$.
$0.01 ; t=3.169)$ in $\mathrm{P} 10$ males $\left(0.043 \pm 0.006 \mathrm{~mm}^{3}\right)$ compared with P10 females $\left(0.020 \pm 0.007 \mathrm{~mm}^{3}\right)$. Thus, the androgen-binding studies support our conclusion that functional ARs are not present in the caudal neostriatum before P9.

For these reasons we conclude that the sex difference in the size of the AR-defined $\mathrm{HVc}$ cannot be explained by genomic androgen- or estrogen-dependent actions in this area because there are no ARs and ERs before P9. Next we analyze whether androgens or estrogens act somewhere else and induce the sexspecific induction of ARs in the HVc by transsynaptic mechanisms or act locally by nongenomic mechanisms.

\section{The AR expression pattern is both independent from gonadal steroids and intrinsic to the caudal forebrain by $5 \mathrm{~d}$ posthatching}

First we demonstrate that the HVc appears to lack connections with other areas that express AR mRNA at P5-P7. Even very large pressure injections of BDA into the putative $\mathrm{HVc}$ area at $\mathrm{P} 5-\mathrm{P} 7$ resulted in neither retrograde labeling of the three input areas of $\mathrm{HVc}$, mMAN (nucleus magnocellularis anterioris medialis), Nif (nucleus interfascialis), and Uva (nucleus uvaeformis) nor in anterograde labeling of the RA and the area $\mathrm{X}$ (the two projection fields of the $\mathrm{HVc}$ ). AR mRNA in the mMAN was found only in zebra finches older than P8 (data not shown). BDA-labeled somas occurred primarily around the injection sites and in some neostriatal areas that did not, however, contain AR mRNA or ER mRNA (data not shown). This neostriatal labeling is most likely caused by the large BDA injection surpassing the borders of the putative $\mathrm{HVc}$.
To determine whether the AR expression is independent from diffusible steroid-induced factors, we prepared slice cultures of the caudal neostriatum of 10 males and 10 females at P5 when $\mathrm{HVc}$ has no afferents and efferents, $4 \mathrm{~d}$ before ARs are expressed in the caudal neostriatum in vivo. In slices of seven females and six males we obtained AR mRNA-expressing cells in the caudal neostriatum after 5-8 DIV (Table 1). In all cases, the number of ARs in the caudal neostriatum at 5-8 DIV was smaller than the number found in the brains of P9 males or females (Table 1). This reduced expression of AR could be attributable to the loss of $\mathrm{HVc}$ cells in the culture conditions. Nevertheless, male-female comparisons showed that male slices contain significantly more AR mRNA-expressing cells than female slices $(p<0.01 ; t=$ 3.106) (Table 1). Therefore, the spatiotemporal signals that induce the expression of AR mRNA in the HVc are already present in the caudal neostriatum at P5 and are independent of the action of gonadal steroids after this point.

\section{The growth pattern of the HVc}

We next analyze the consequences of the genetically determined sex difference for the further development of the HVc, in particular in light of the hormone sensitivity of the HVc development. The HVc increases in size by extension during the posthatching period. Between P15 and P30, the AR mRNA-defined HVc increases 2.7-fold in volume (Fig. 2). Because the X-projecting $\mathrm{HVc}$ neurons retrogradely labeled at P15 were distributed throughout the entire HVc identified by AR mRNA at P15 and at 


\section{HVC-development of the zebra finch}

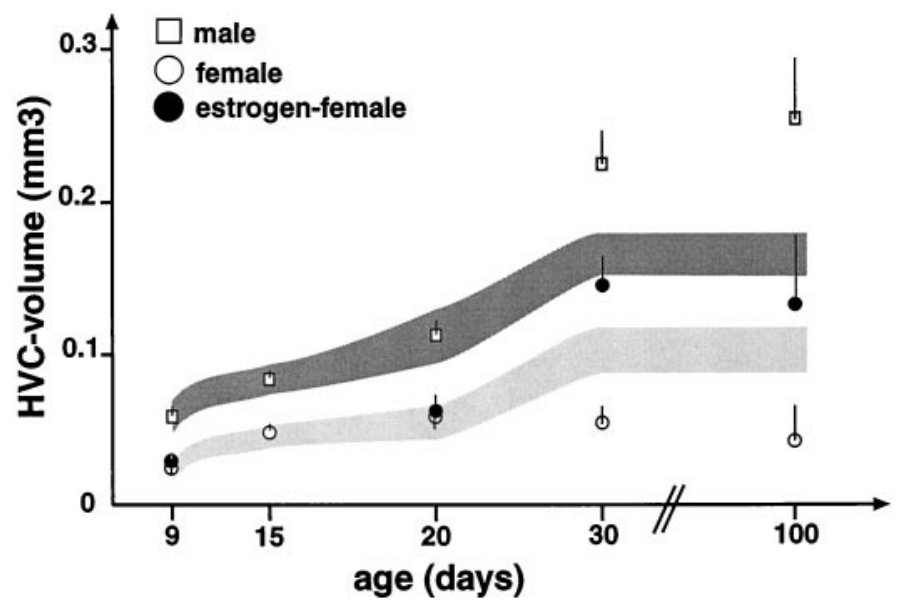

Figure 2. Steroid-independent and steroid-dependent development of the $\mathrm{HVc}$ volume. The $\mathrm{HVc}$ was defined by the distribution of AR mRNA in the caudal neostriatum. For each age group, the male $\mathrm{HVc}(\square)$ is larger $(p<0.001 ; t=3.46)$ compared with the female $\mathrm{HVc}(\bigcirc)$. The male $\mathrm{HVc}$ volume increases significantly from P9 to P15 to P20 to P30 ( $p<0.001$; $t=3.46)$ to $\mathrm{P} 100(p<0.01 ; t=2.66)$. The dark gray band indicates the expected growth of the $\mathrm{HVc}$ based on its genetically determined size at P9 and the subsequent extension of the forebrain. The male $\mathrm{HVc}$ grows linearly with the caudal neostriatum until P20 but grows faster than the forebrain after P20. In females, the HVc volume increases from P9 to P15 to $\mathrm{P} 20(p<0.01 ; t=2.66)$ but does not undergo significant increase or decrease afterward. The female HVc grows less than expected after P20 (light gray band). In estrogen-treated females $(\bullet)$, the HVc volume increases significantly after P20 compared with normal females $(p<0.001$; $t=3.46$ ) and compared with the expected value (light gray band). Thus epigenetic factors such as estrogens induce a $30-40 \%$ increase of the $\mathrm{HVc}$ size after P20, whereas $60-70 \%$ of the maximal $\mathrm{HVc}$ size is defined by steroid-independent mechanisms.

P30, HVc growth is caused by increased spacing of an initial neuronal scaffold (Fig. 4). Likewise, the size of the caudal forebrain (in which HVc develops) increases in males and females between P9 and P30 in the rostrocaudal, mediolateral, and dorsoventral dimension by $1.4 \pm 0.1$-fold, $1.5 \pm 0.15$-fold, and $1.4 \pm$ 0.2 -fold, respectively, and thus its volume increased by an average of 2.9-fold. From the extension of the forebrain and the HVc size at P9, we can predict a growth curve of the HVc of males (Fig. 2, dark gray band) and females (Fig. 2, light gray band) under the assumption that it extents linearly with the forebrain.

Until P20, the HVc and the forebrain expand at the same rate, and thus passive growth explains the entire male $\mathrm{HVc}$ volume at P20 (Fig. 2). After P20, the male HVc increases 2.3-fold in volume (Fig. 2), whereas the caudal forebrain expands 1.5 -fold. Thus after P20, the male HVc increases faster than the caudal forebrain, which indicates the action of epigenetic factors such as estrogens on HVc extension. In agreement, the HVc of estrogentreated females grows linearly with the forebrain until P20 and faster than the forebrain after P20 (Fig. 2). These results suggest that $60-70 \%$ of the HVc growth of males can be explained by genetic brain-autonomous mechanisms, i.e., its initial genetically determined sex-specific size at P9 and the subsequent extension of the entire forebrain. Thus epigenetic factors are involved in $\mathrm{HVc}$ growth but control only $30-40 \%$ of the HVc volume of adult males (Fig. 2).
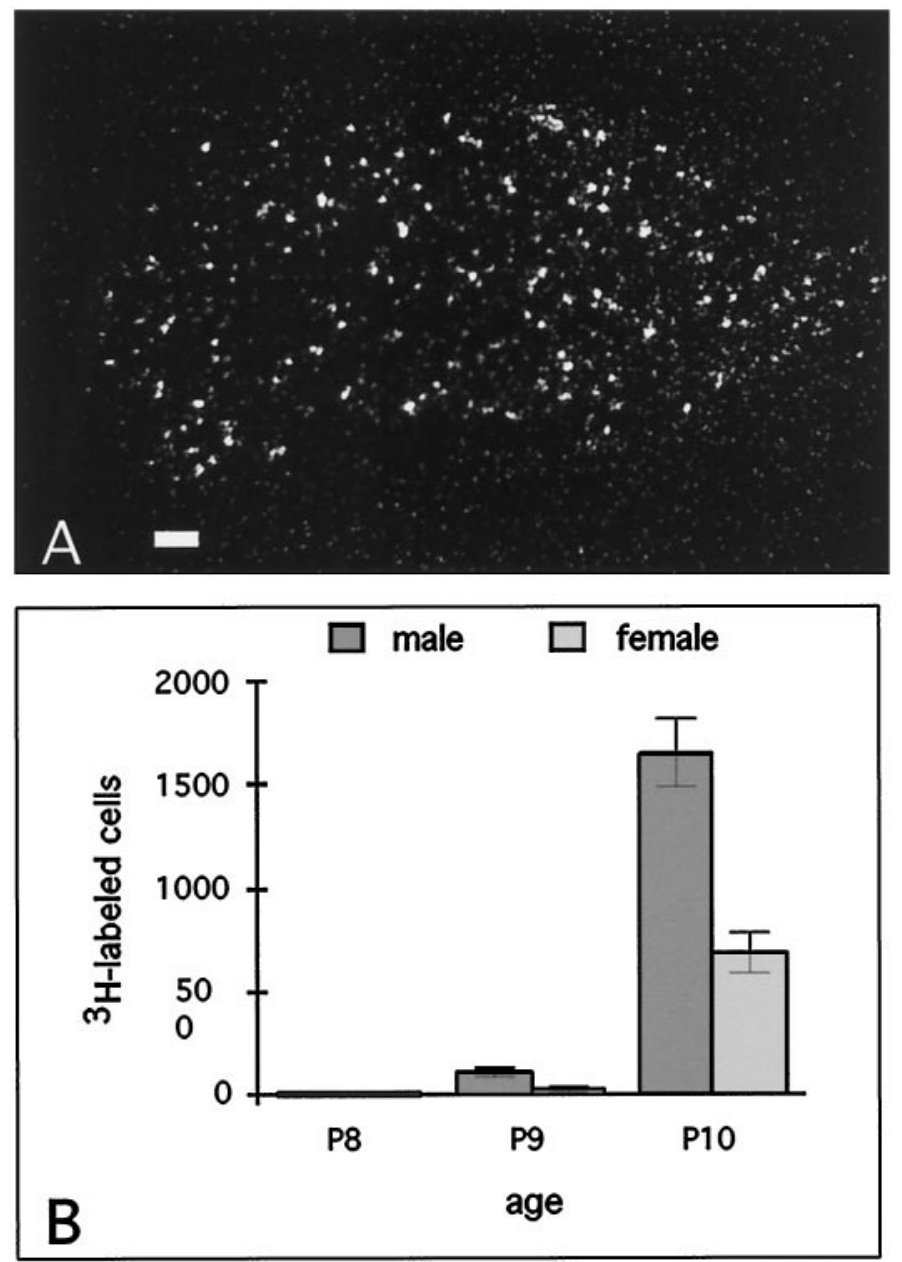

Figure 3. The development of androgen binding in the HVc visualized with the injection of $\left[{ }^{3} \mathrm{H}\right]-5 \alpha$-dihydrotestosterone in an in vivo autoradiographical procedure. In $A$, the dark-field photomicrograph of an autoradiogram of the $\mathrm{HVc}$ of a P10 male is shown. A large number of densely labeled cells are distributed throughout HVc. In $B$, the number of ${ }^{3} \mathrm{H}$-labeled cells at P8, P9, and P10 (mean \pm SD) is quantified. Labeled cells were found in the $\mathrm{HVc}$ area only from $\mathrm{P} 9$ onward.

Table 1. Slices of the HVC of both males and females express AR mRNA in a steroid-free environment but the number of AR mRNAexpressing cells is sexually dimorphic ${ }^{a}$

Number of AR mRNA-expressing HVC cells

\begin{tabular}{lll} 
& In vivo & In vitro \\
\hline Male & $2210 \pm 435(n=10)$ & $710 \pm 247(n=7)$ \\
Female & $1045 \pm 272(n=10)$ & $185 \pm 135(n=6)$
\end{tabular}

Given are the numbers of AR mRNA-containing cells in the HVC in vitro (5-8 $\mathrm{DIV})$ and in vivo at $\mathrm{P} 9$ (mean $\pm \mathrm{SD}$ ). The spatiotemporal signals that induce the expression of $\mathrm{AR}$ in the $\mathrm{HVC}$ are already present in the caudal neostriatum at P5 and are independent from the action of steroid hormones at this point. ${ }^{a} p<0.01 ; t=3.106$.

\section{DISCUSSION}

The sexually dimorphic expression of AR in the HVc develops independent of gonadal steroids

The sexually dimorphic period of the HVc is thought to start at posthatching day $12-20$, whereas the HVc is described to be monomorphic in size before then (Bottjer et al., 1985; Kirn and 

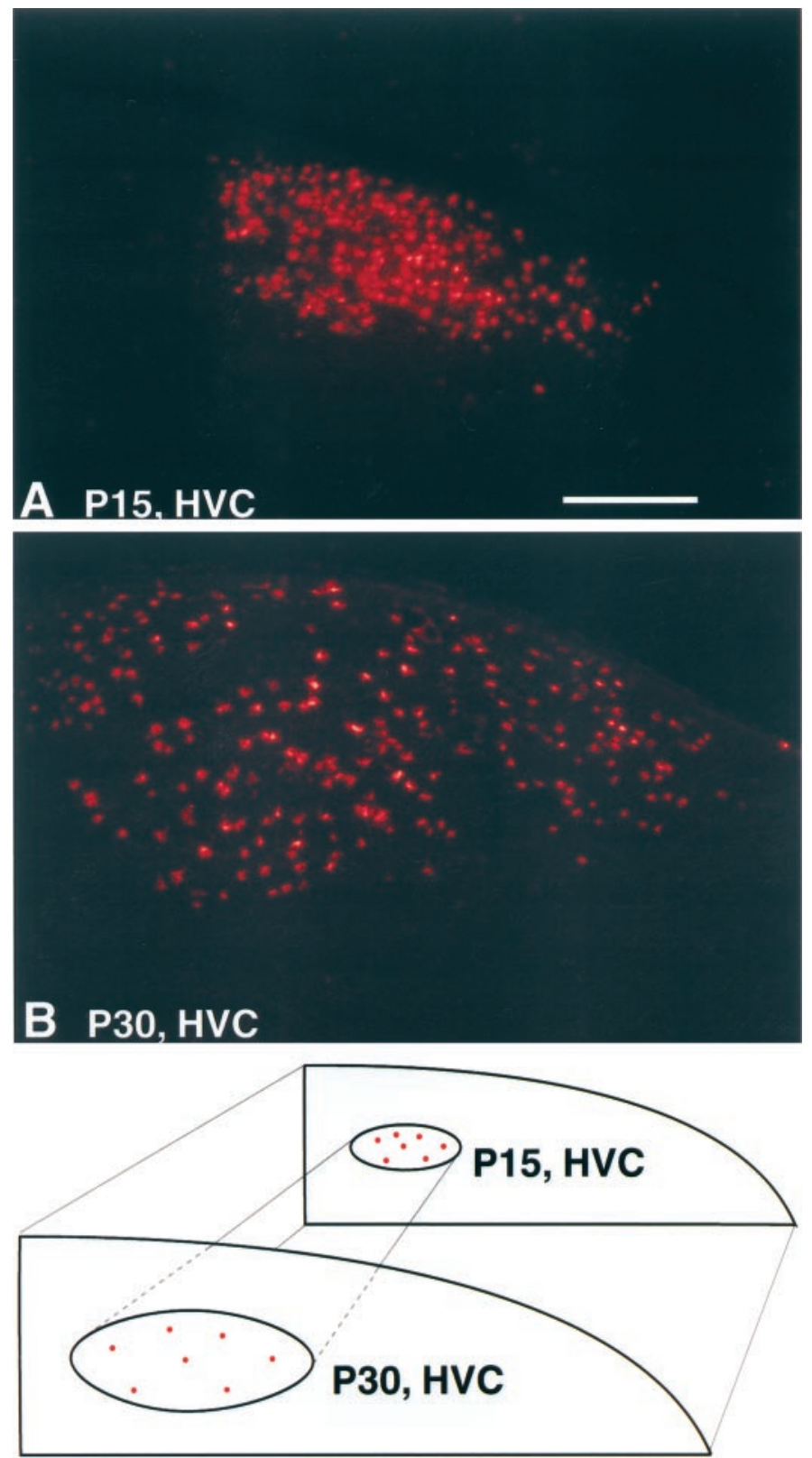

\section{HVC grows by extension}

Figure 4. The HVc grows by extension in the caudal forebrain. In $A$ the retrogradely labeled $\mathrm{HVc}$ of a $\mathrm{P} 15$ male is shown, and in $B$ the retrogradely labeled $\mathrm{HVc}$ of a $\mathrm{P} 30$ male is shown. In both cases the entire $\mathrm{HVc}$ was labeled after injection of rhodamine-coated latex microspheres into area X of P13 animals. The total number of retrogradely labeled neurons was similar $(p>0.05 ; t=3.306)$ between P15 (9500 \pm 1800$)$ and P30 $(10,300 \pm 1,950)$ males, but the density of X-projecting neurons at P15 $\left(5.6 \pm 1.6 / 50,000 \mu \mathrm{m}^{3}\right)$ and P30 $\left(2.2 \pm 0.6 / 50,000 \mu \mathrm{m}^{3}\right)(p<0.01 ; t=$ $3.355)$ is dramatically different. Thus $\mathrm{HVc}$ grows by spacing out of neurons present in the $\mathrm{HVc}$ at $\mathrm{P} 15$. In $C$, the proportional extension of the $\mathrm{HVc}$ and the caudal forebrain between P15 and P30 is shown in a schematic drawing. Scale bar, $50 \mu \mathrm{m}$.

DeVoogd, 1989; Nixdorf-Bergweiler, 1996). In adulthood as well as in older ontogenetic stages, the $\mathrm{HVc}$ contains many AR mRNA-expressing cells (this study) and some ER mRNAexpressing cells (Gahr and Konishi, 1988; Gahr, 1996). Because androgens and estrogens affect brain differentiation by binding to their cognate receptors (for review, see McEwen, 1992), the expression of these receptors in the HVc should precede its sexually dimorphic development and be monomorphic before this period.

Indeed, the ER distribution in the caudomedial neostriatum of male and female zebra finches is similar during early development of the HVc (Gahr, 1996). Because ERs are expressed in the HVc only at P15 (Gahr, 1996; this study) when HVc is already sexually dimorphic in size (Fig. 2) and neuron number, ERdependent mechanisms are not involved in the initial sexually dimorphic development of the HVc.

Similarly, local AR-dependent mechanisms are unlikely to control the initial sexually dimorphic development of the $\mathrm{HVc}$ because the AR distribution is highly sexually dimorphic at the first time of AR expression in the caudal neostriatum (Fig. 1). To evaluate whether this result depends on the in situ hybridization method for the localization of ARs, i.e., whether ARs are expressed in the HVc area before P9 in a monomorphic pattern, we performed RT-PCR for AR mRNA and androgen-binding studies. For the RT-PCR, tissue samples of the hypothalamus and caudal forebrain (in which HVc develops in songbirds) of P8 male zebra finches, adult male zebra finches, and ring doves were used. The caudal forebrain of the ring dove served as negative control because this tissue does not contain AR (Kim et al., 1978) and does not express AR mRNA in in situ hybridizations (Metzdorf et al., 1999). With use of nested primers, AR mRNA was detected in all tissues analyzed, including the ring dove caudal forebrain. Thus, either most brain areas of birds contain ARs at very low but physiologically meaningful levels, or our RT-PCR results reflect noise from the transcription machinery, so-called illegitimate transcription (Chelly et al., 1989). We can exclude procedural problems as an explanation for the lack of AR mRNA localization in the caudal neostriatum in the in situ hybridizations because we localized AR mRNA in the adjacent hippocampus of ring doves (Metzdorf et al., 1999) and P8 zebra finches (Fig. 1B). The hippocampus overlays the caudal neostriatum (Fig. $1 B$ ); thus, a further explanation for the RT-PCR result is that the neostriatal tissue samples used for the RT-PCR were contaminated with nearby hippocampal tissue, which expresses AR mRNA. Androgen-binding cells were found in several brain areas including the hippocampus but not in the HVc area of the zebra finch before P9. This suggests that the AR protein is present in several brain areas but not in the HVc before P9 and that the sex difference in DHT binding at P10 is not caused by a sex-specific secretion of steroids from the gonads.

From the combination of in situ hybridizations, in vivo autoradiography, and RT-PCR we conclude that functional ARs are not present in the HVc before P9. Although it is well known that the AR is autoregulated (Tan et al., 1988; Nastiuk and Clayton, 1994), the spatiotemporal signals that control the first developmental expression of AR in the $\mathrm{HVc}$ or in any other tissue are currently unknown. Steroid-dependent regulation of AR explains only quantitative sex differences in the amount of steroid receptor expression, as reported for several brain areas (Lisciotto and Morrell, 1993; Kühnemann et al., 1994), but does not explain sex differences in the tissue distribution of ARs in the brain as seen in the HVc area of zebra finch nestlings. Thus, because neither ARs nor ERs are expressed before P9 in the developing HVc, local genomic androgen- or estrogen-dependent effects cannot be responsible for the initial sexual size dimorphism of the $\mathrm{HVc}$ or its AR mRNA expression pattern.

We wanted to know whether connectional information or trophic substances released from other steroid-sensitive brain areas 
were required for the AR expression in the HVc area and thus for the initial sexual dimorphism of the HVc. The tract-tracing studies show that $\mathrm{HVc}$ is not connected monosynaptically with other brain areas that express AR mRNA or ER mRNA before P9. These results exclude steroid-mediated trophic retrograde and anterograde transsynaptic effects as a mechanism for either AR mRNA expression or the sex difference in size of the developing HVc. However, some sexually dimorphic signal could spread via diffuse connectional pathways or via diffusible factors to the HVc from other brain areas that express ARs or ERs before the developing song system does. Such steroid-dependent factors could then induce the sexually dimorphic development of HVc size and AR expression. One such area may be the hypothalamic-preoptic area that expresses high levels of AR and ER well before hatching at E10 (Gahr and Metzdorf, 1997). The HVc lacks afferents and efferents with AR- or ER-containing areas at P5. In slice cultures of the caudal neostriatum of P5 zebra finches, however, AR mRNA expression is upregulated in vitro in a steroid-free environment, and this induction is sexually dimorphic (Table 1). Therefore, the spatiotemporal signals that induce the expression of AR mRNA in the HVc are already present in the caudal neostriatum at P5 and are independent of the action of gonadal steroids after this point. Furthermore, the slice culture experiment excludes nongenomic actions of androgens and estrogens, i.e., those not involving ARs and ERs (Wehling, 1997), as an explanation for the development of sex differences of the $\mathrm{HVc}$ after P5 because there were no steroids in the cultures.

Alternatively to such mechanisms intrinsic to the caudal neostriatum, AR-expressing HVc cells might originate at more distant sites along the ventricular zone of the caudal forebrain and transiently express sex-steroid receptors before P5 and before migrating into the HVc. In this case, sex steroid-steroid receptordependent mechanisms could prime the prospective $\mathrm{HVc}$ cells before they reach $\mathrm{HVc}$ to express ARs later or could facilitate the migration of such cells into the $\mathrm{HVc}$ area. To analyze this possibility, we studied the expression of ARs in the entire forebrain from E10 onward; E10 was the first time when we were able to localize AR mRNA in the zebra finch brain (Gahr and Metzdorf, 1997). There are no AR mRNA-expressing cells along the ventricular zone or elsewhere in the caudal neostriatum before P5, the time at which we prepared the cultures of the caudale forebrain. This suggests that AR mRNA expression of putative HVc cells starts only after they migrate into the HVc area.

Thus the remaining possibilities for a steroid-dependent development of the AR expression pattern in the HVc are (1) a sex steroid-dependent nongenomic priming of putative HVc cells to later produce AR mRNA and (2) a sex steroid-dependent trophic or transsynaptic signaling from nontelencephalic areas such as the hypothalamic-preoptic area before P5. Sex differences in the level of circulating androgens and in the steroid production in the brain of juvenile zebra finches until P5, however, were not shown (Hutchison et al., 1984; Schlinger and Arnold, 1992). Furthermore, it is unclear at present whether there are sex differences in circulating estrogen levels in juvenile zebra finches at any age (Balthazart and Ball, 1995). We suggest, therefore, that there are brain-autonomous mechanisms that control the development of brain sex independent of gonadal steroids. This notion is an agreement with a series of recent investigations (Wade and Arnold, 1996; Wade et al., 1996) that reported that sex reversal of the zebra finch gonad morphology has little or no effect on the sex of the vocal control system.

\section{The relation of brain-intrinsic and epigenetic- controlled growth of the HVc}

From the growth pattern of HVc we predict that $60-70 \%$ of the $\mathrm{HVc}$ growth of males can be explained by steroid-independent brain-autonomous mechanisms, i.e., its initial genetically determined size at P9 and the subsequent extension of the entire forebrain (Figs. 2, 4). These findings explains why anti-steroid treatments fail to feminize the size of vocal control areas of male zebra finches (Balthazart et al., 1994; Wade and Arnold, 1994; Merten and Stocker-Buschina, 1995).

Epigenetically controlled growth explains $30-40 \%$ of the $\mathrm{HVc}$ volume of males (Fig. 2). The work conducted with female zebra finches suggests that testosterone and estrogens are involved in this epigenetically controlled growth of the male HVc [Gurney and Konishi, 1980; Gurney, 1982; Simpson and Vicario, 1991; Adkins-Regan et al., 1994; Grisham et al., 1994; Burek et al., 1995, 1997; this study (Fig. 2)]. The assumption of a male-like hormone-dependent fraction $(30-40 \%)$ in the growth of the female HVc after P20 would explain why estrogen treatment does not lead to a monomorphic nucleus and predicts the H Vc volume that we measured in our estrogen-treated females (Fig. 2). Alternatively (but see above), sex steroids might not be at all involved in the epigenetic fraction of HVc growth, because female zebra finches that develop large amounts of testicular tissue attributable to endocrine manipulations in early embryonic life still develop a female-like neural vocal control circuit (Wade and Arnold, 1996; Wade et al., 1996).

\section{Brain sex-determining factors intrinsic to the brain as a concept for sexual differentiation}

Our results support the notion that sexual differentiation of the brain does not in all cases depend on sex steroids (Reisert and Pilgrim, 1991; Balthazart and Ball, 1995; Arnold, 1996, 1997; Casto and Ball, 1996; Schlinger, 1998). As one possible mechanism for the development of brain sex, we propose that there are brain sex-determining factors intrinsic to the brain (Fig. 5). In the zebra finch, such factors should control the sex-specific expression of AR mRNA in the HVc and thus the HVc size. Concomitantly, Gahr and Balaban (1996) showed that the signals for the tissuespecific expression of steroid receptors in the hypothalamus are intrinsic to the brain as early as E2 in the Japanese quail, a gallinaceous bird, before sexual differentiation of the gonad has taken place. We suggest further that epigenetic factors can modify but not overwrite the brain-autonomously determined sex difference of the $\mathrm{HVc}$ because genetically determined factors control $60-70 \%$ of the HVc growth. A brain-autonomously determined sex difference in androgen receptor expression in the $\mathrm{HVc}$ would lead to a sex difference in further HVc development even if the hormone availability in the brain is similar in males and females throughout life. Therefore, AR-dependent mechanisms are not responsible for the sexual differentiation of the $\mathrm{HVc}$ but might be important for the functional development of the HVc in either sex and thus for intra-sex variability. To validate such a role of androgens it would be important to know whether the testicular tissues of sex-reversed females (Wade and Arnold, 1996) produce any androgens during development.

Steroid-independent mechanisms of sexual differentiation in vertebrates have been clearly shown for some somatic features such as the pouch and scrotum of marsupials (Renfree, 1993). Brain-intrinsic modes of sexual differentiation are well known, however, for invertebrates. In Drosophila melanogaster the development of sexual dimorphisms of the nervous system is cell 


\section{New model for sexual differentiation}

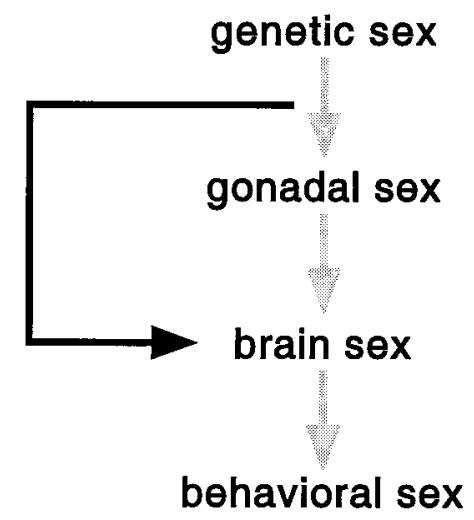

Figure 5. A new model for the sexual differentiation of brain and behavior in higher vertebrates. Most current models of sexual differentiation of brain and behavior (gray arrows) suggest that the epigenetic action of gonadal steroids controls brain sex entirely. In difference, we propose brain sex-determining factors that control brain sex by brain-autonomous mechanisms (black arrow), independent of or in concert with gonadal steroid-dependent mechanisms. Environmental and behavioral determination of gonadal sex are neglected here for simplicity (for review, see Crews, 1993).

autonomous (Belote and Baker, 1987; Possidente and Murphey, 1989). In Caenorhabditis elegans, both cell-autonomous and epigenetic mechanisms interact during sexual differentiation (Parkhurst and Meneely, 1994). The zebra finch might have evolved the mechanism of decoupling sexual differentiation in part from gonadal development to avoid partial masculinization of the vocal behavior of females because both male and female zebra finches have a very active estrogen synthase in the forebrain (Schlinger and Arnold, 1992). Reexamination of the early development of sexually dimorphic brain areas of other vertebrates using noncytoarchitectural criteria to delineate these brain areas and in vitro slice culture techniques should indicate whether brain-autonomous, steroid-independent mechanisms of sexual differentiation are common or are restricted to sex-specific (i.e., those limited to one sex) systems such as the singing of zebra finches.

\section{REFERENCES}

Adkins-Regan E, Mansukhani V, Seiwert C, Thompson R (1994) Sexual differentiation of brain and behaviour in the zebra finch: critical periods for effects of early estrogen treatment. J Neurobiol 25:865-877.

Arnold AP (1996) Genetically triggered sexual differentiation of brain and behavior. Horm Behav 30:495-505.

Arnold AP (1997) Sexual differentiation of the zebra finch song system: positive evidence, negative evidence, null hypotheses, and a paradigm shift. J Neurobiol 33:572-584.

Balthazart J, Ball GF (1995) Sexual differentiation of brain and behavior in birds. Trends Endocrinol Metab 6:21-29.

Balthazart J, Absil P, Fiasse V, Ball GF (1994) Effects of the aromatase inhibitor R76713 on sexual differentiation of brain and behavior in zebra finches. Behaviour 131:225-260.

Belote JM, Baker BS (1987) Sexual behaviour: its genetic control during development and adulthood in Drosophila melanogaster. Proc Natl Acad Sci USA 84:8026-8030.

Bottjer SW, Glaessner SL, Arnold AP (1985) Ontogeny of brain nuclei controlling song learning and behavior in zebra finches. J Neurosci 5:1556-1562.

Burek MJ, Nordeen KW, Nordeen EJ (1995) Estrogen promotes neuron addition to an avian song-control nucleus by regulating post-mitotic events. Brain Res Dev Brain Res 85:220-224.

Casto JM, Ball GF (1996) Early administration of 17b-estradiol partially masculinizes song control regions and a2-adrenergic receptor distribution in European starlings (Sturnus vulgaris). Horm Behav 30:387-406.

Chelly J, Concordet JP, Kaplan JC, Kahn A (1989) Illegitimate transcription of any gene in any cell type. Proc Natl Acad Sci USA 86:2617-2621.

Coggeshall RE (1992) A consideration of neural counting methods. Trends Neurosci 15:9-13.

Conover W (1980) Practical non-parametric statistics, Ed 2. New York: Wiley.

Crews D (1993) The organizational concept and vertebrates without sex chromosomes. Brain Behav Evol 42:202-214.

Döhler KD, Hancke JL, Srivastava SS, Hofmann C, Shiryne JE, Gorski RA (1984) Participation of estrogens in female sexual differentiation of the brain: neuroanatomical, neuroendocrine and behavioral evidence. Prog Brain Res 61:99-117.

Gahr M (1990) Delineation of a brain nucleus: comparisons of cytochemical, hodological, and cytoarchitectural views of the song control nucleus HVc of the adult canary. J Comp Neurol 294:30-36.

Gahr M (1996) Developmental changes in the distribution of estrogen receptor mRNA expressing cells in the forebrain of female, male, and masculinized female zebra finches. NeuroReport 7:2469-2473.

Gahr M, Balaban E (1996) The development of a species difference in the local distribution of brain estrogen receptive cells. Dev Brain Res 92:182-189.

Gahr M, Konishi M (1988) Developmental changes in estrogen-sensitive neurons in the forebrain of the zebra finch. Proc Natl Acad Sci USA 85:7380-7383.

Gahr M, Metzdorf R (1997) Distribution and dynamics in the expression of androgen and estrogen receptors in vocal control systems of songbirds. Brain Res Bull 44:509-517.

Grisham W, Mathews GA, Arnold AP (1994) Local intracerebral implants of estrogen masculinize some aspects of the zebra finch song system. J Neurobiol 25:185-196.

Gurney ME (1981) Hormonal control of cell form and number in the zebra finch song system. J Neurosci 1:658-673.

Gurney ME (1982) Behavioral correlates of sexual differentiation in the zebra finch song system. Brain Res 231:153-173.

Gurney ME, Konishi M (1980) Hormone-induced sexual differentiation of brain and behavior in zebra finches. Science 208:1380-1383.

Hutchison JB, Wingfield JC, Hutchison RE (1984) Sex differences in plasma concentrations of steroids during the sensitive period of brain differentiation. J Endocrinol 103:363-369.

Johnson F, Bottjer SW (1995) Differential estrogen accumulation among populations of projection neurons in the higher vocal center of male canaries. J Neurobiol 26:87-108.

Jost A (1983) Genetic and hormonal factors in sex differentiation of the brain. Psychoneuroendocrinology 8:183-193.

Kim Y, Stumpf WE, Sar M, Martinez-Vargas C (1978) Estrogen and androgen target cells in the brain of fishes, reptiles and birds: phylogeny and ontogeny. Am Zool 18:425-433.

Kirn JR, DeVoogd TJ (1989) The genesis and death of vocal control neurons during sexual differentiation in the zebra finch. J Neurosci 9:3176-3187.

Konsihi M, Akutagawa E (1985) Neuronal growth, atrophy and death in a sexually dimorphic song nucleus in the zebra finch brain. Nature 315:145-147.

Konishi M, Akutagawa E (1986) Hormonal control of cell death in a sexually dimorphic nucleus in the zebra finch: selective neuronal death. Ciba Found Symp 126:173-185.

Kühnemann S, Brown TJ, Hochberg RB, MacLusky NJ (1994) Sex differences in the development of estrogen receptors in the rat brain. Horm Behav 28:483-491.

Lisciotto CA, Morrell JI (1993) Circulating gonadal steroid hormones regulate estrogen receptor mRNA in the male rat forebrain. Brain Res 20:79-90.

McEwen BS (1981) Neural gonadal steroid actions. Science 211: 1301-1303.

McEwen BS (1992) Steroid hormones: effect on brain development and function. Horm Res 37[Suppl 3]:1-10. 
Merten MDP, Stocker-Buschina S (1995) Fadrozole induces delayed effects on neurons in the zebra finch song system. Brain Res 671:317-320.

Metzdorf R, Gahr M, Fusani L (1999) The distribution of aromatase-, estrogen receptor- and androgen receptor-mRNA in the forebrain of songbirds and non-songbirds. J Comp Neurol, in press.

Nastiuk KL, Clayton DF (1994) Seasonal and tissue- specific regulation of canary androgen receptor mRNA. Endocrinology 134:640-649.

Nixdorf-Bergweiler BE (1996) Divergent and parallel development in volume sizes of telencephalic song nuclei in male and female zebra finches. J Comp Neurol 375:445-456.

Nottebohm F, Arnold AP (1976) Sexual dimorphism in vocal control areas of the song bird brain. Science 194:211-213.

Parkhurst SM, Meneely PM (1994) Sex determination and dosage compensation: lessons from flies and worms. Science 264:924-932.

Phoenix CH, Goy RW, Gerall AA, Young WC (1959) Organizing action of prenatally administered testosterone propionate on the tissues mediating mating behavior in the female guinea pig. Endocrinology 65:369-382.

Possidente DR, Murphey RK (1989) Genetic control of sexually dimorphic axon morphology in Drosophila sensory neurons. Dev Biol 132:448-457.

Reisert I, Pilgrim C (1991) Sexual differentiation of monoaminergic neurons: genetic or epigenetic? Trends Neurosci 14:468-473.

Reisert I, Lieb K, Beyer C, Pilgrim C (1996) Sex differentiation of rat hippocampal GABAergic neurons. Eur J Neurosci 8:1718-1724.

Renfree M (1993) Gonadal and genital differentiation: the sexual takeover of the excretory system. In: The differences between the sexes (Short R, Balaban E, eds), pp 213-230. Cambridge, UK: Cambridge UP.

Schlinger BA (1998) Sexual differentiation of avian brain and behavior: current views on gonadal hormone-dependent and independent mechanisms. Annu Rev Physiol 60:407-429.

Schlinger BA, Arnold AP (1992) Plasma sex steroids and tissue aroma- tization in hatchling zebra finches: implications for the sexual differentiation of singing behavior. Endocrinology 130:289-299.

Sibug R, Kuppers E, Beyer C, Maxson SC, Pilgrim C, Reisert I (1996) Genotype-dependent sex differentiation of dopaminergic neurons in primary cultures of embryonic mouse brain. Dev Brain Res 93: $136-142$.

Simpson HB, Vicario DS (1991) Early estrogen treatment of female zebra finches masculinizes the brain pathway for learned vocalizations. J Neurobiol 22:777-793.

Tan JA, Joseph DR, Quarmby VE, Luban DB, Sar M, French FS, Wilson EM (1988) The rat androgen receptor: primary structure, autoregulation of its messenger RNA and immunocytochemical localization of the receptor protein. Mol Endocrinol 2:1276-1285.

Wade J, Arnold A (1994) Posthatching inhibition of aromatase-activity does not alter sexual-differentiation of the zebra finch song system. Brain Res 639:347-350.

Wade J, Arnold A (1996) Functional testicular tissue does not masculinize development of the zebra finch song system. Proc Natl Acad Sci USA 93:5264-5268.

Wade J, Springer ML, Wingfield JC, Arnold AP (1996) Neither testicular androgens nor embryonic aromatase activity alters morphology of the neural song system in zebra finches. Biol Reprod 55:1126-1132.

Wehling M (1997) Specific, nongenomic actions of steroid hormones. Annu Rev Physiol 59:365-393.

Whalen RE (1974) Sexual differentiation: models, methods, and mechanisms. In: Sex differences in behavior (Friedman RC, Richart RH Wiele RLV, eds), pp 467-184. New York: Wiley.

Whitfield Jr HJ, Brady L, Smith MA, Mamalaki E, Fox RJ, Herkenham M (1990) Optimization of cRNA probe in situ hybridization methodology for localization of glucocorticoid receptor mRNA in rat brain: a detailed protocol. Cell Mol Neurobiol 10:145-157. 